\title{
Bilateral power supply of the traction network as a first stage of Smart Grid technology implementation in electric traction
}

\author{
Mikołaj Bartłomiejczyk ${ }^{1, *}$ \\ ${ }^{1}$ Gdansk University of Technology, Faculty of Electrical and Control Engineering, ul. Narutowicza 11/12 G, 80-233 Gdańsk, Poland
}

\begin{abstract}
Since 2001, trolleybus system in Gdynia has been involved in many activities related to the reduction of power consumption, both in terms of implementation and research and development. In PKT, in cooperation with SESTO company, started applications of Smart Grid technologies in supply network: the bilateral supply. The paper presents results of this this novel investment.
\end{abstract}

\section{Introduction}

The city of Gdynia, Poland, exploits an extensive, 50-kmlong trolleybus network, which is serviced by 85 vehicles. This network is supplied from 10 traction substations with $600 \mathrm{~V}$ DC. The trolleybus system is operated by Przedsiębiorstwo Komunikacji Trolejbusowej Sp. z o.o. (PKT) which, for a number of years, has been working towards limiting energy consumption [1]. Vehicles with power electronic drive system are gradually introduced and, consequently, energy consumption has decreased by more than $20 \%$ over the past 10 years. In the years 2009 2012 PKT conducted comprehensive modernisation of the supply system, which resulted in the increase of its reliability and in the decrease of transmission losses [2]. PKT also carries out scientific and research activities connected with reducing energy consumption.

\section{Bilateral supply system}

The possibility to work in reverse mode, as generators of electric energy, is a characteristic feature of electric motors [3-6]. It allows to change kinetic energy of a vehicle into electric energy, which can then be returned to the traction supply system and consumed by other vehicles. However, when there is no possibility to receive recuperated energy we lose the energy which could potentially be recovered.

In a classic supply system each of the contact line sections is supplied solely from one substation, so the supply areas of individual substations are galvanic separated from each other. In the case of low traffic intensity or small substation areas, there may occur a situation where there is no vehicle which could absorb the recuperation energy from a braking vehicle [7]. However, it is possible to increase the change of finding a recipient of the generated energy by joining the supply area with the neighbouring substation, thus allowing for the flow of recuperation energy to the area of that neighbouring substation. Such a situation has been presented schematically in Fig. 1.

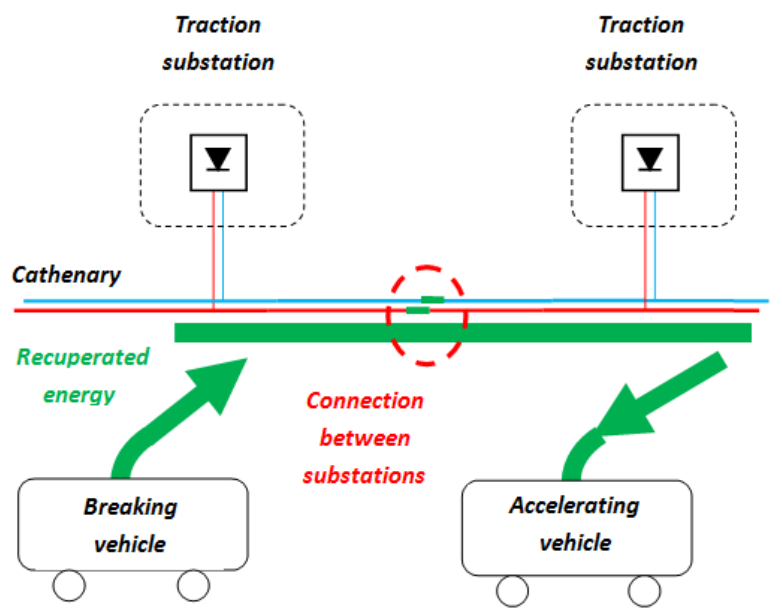

Fig. 1. Diagram of recuperation energy flow between braking vehicle and accelerating vehicle in bilateral contact line supply system.
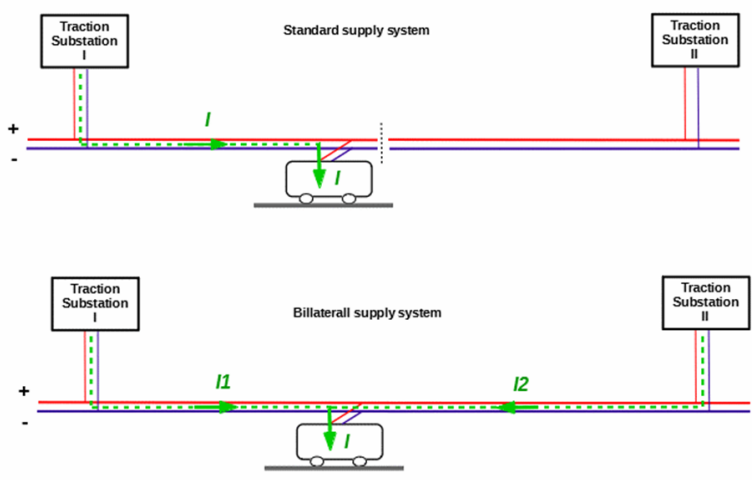

Fig. 2. Comparison of vehicle current distribution between supply traction substations.

\footnotetext{
* Corresponding author: mikolaj.bartlomiejczyk@.pg.edu.pl
} 
Bilateral supply also allows to reduce the voltage losses in overhead catenary, what is presented on Fig. 2. In bilateral supply the vehicle can be supplied in two ways, so the vehicle current I can be distributed between two smaller substation load currents I1 and I2, which reduces the load of catenary and voltage losses.

Bilateral power supply can also be applied for upgrading classic central supply system with large substations. Then it is possible to supply the traction section of the traction network in two places by means of cable feeders coming out of one substation. Such situations shown in Fig. 3.

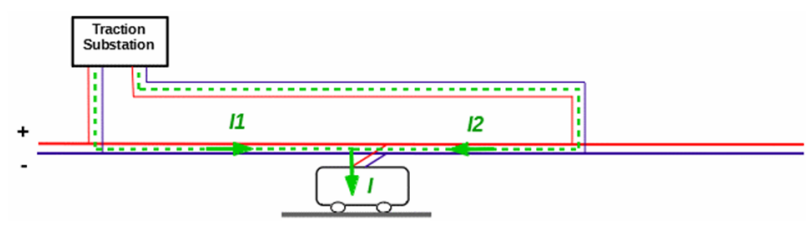

Fig. 3. Bilateral supply system with one substation.

\section{Implementation of bilateral supply system in Gdynia's trolleybus network}

In June 2016 PKT Gdynia, in cooperation with company SESTO, began practical implementation of Smart Grid technology within the exploited trolleybus system. This task was realised in the year 2016, within the Eliptic "Electrification of public transport in cities" H2020 project. The bilateral supply system was applied in 3 parts of Gdynia's trolleybus network (Fig. 6):

1) between substations Grabówek and Dworzec, on one of the most exploited trolleybus lines,

2) between two sections, which are both supplied from one substation Redłowo,

3) between substations Sopot and Sopot I, on interurban line with low traffic.

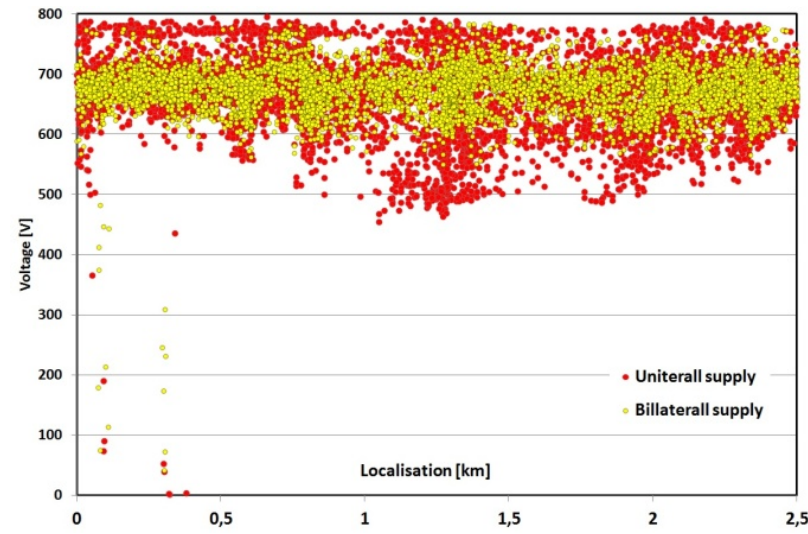

Fig. 4. Spread of the voltage values in area of substations Dworzec - Grabówek in catenary before and after implementation of bilateral supply.
These three places reflect different possible traffic conditions and power supply structures: line with high traffic and high voltage drops (1) which corresponds to situation on Fig. 2, two sections supplied from one substation (2) which corresponds to situation on Fig. 3 and line with low traffic and low usage of breaking energy recovery (3) which corresponds to situation on Fig. 1.

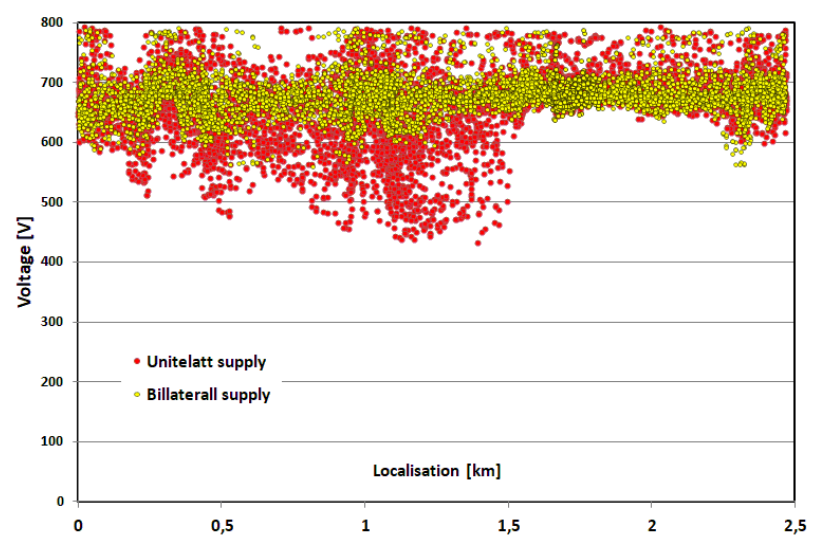

Fig. 5. Spread of the voltages value in area of substation Redłowo in catenary before and after implementation of bilateral supply.

The bilateral supply system was realised as a software integrated with the remote control system of trolleybus substation in Gdynia. The software was developed by SESTO company, which was a supplier of a control system equipment and software of all trolleybus substation in Gdynia. The bilateral supply system and substation protection devices were based only on the internet connection between substation, which was the main challenge of this system.

The introduction of bilateral supply between substation Sopot I and Sopot Reja resulted visible in the increase of recuperation effectiveness and slightly in the reduction of energy transmission losses (Table 1). In case of substations Dworzec - Grabówek and Redłowo, the implementation of bilateral supply significantly reduced the voltage drops (Table 1, Figs. 4 and 5). Voltage stability was improved, what is visible on graph of the spread of voltage values (Figs. 4 and 5). The analysis was made on the basis of the vehicle data loggers registrations. Registrations consist values of electrical parameters of the vehicle and GPS localisation in each second. In case of substations Dworzec and Redłowo after implementation of bilateral supply system the spread of voltage points was narrowed from both side - lower and upper part. Reduction of the lower part means the reduction of voltage drops caused by voltage loses in catenary. The horizontal upper limit of this group means the no-load substation voltage, which corresponds to the situation where there is no receiver for recuperated energy. Consequently, reduction of the upper part means the better usage of recuperated energy. 


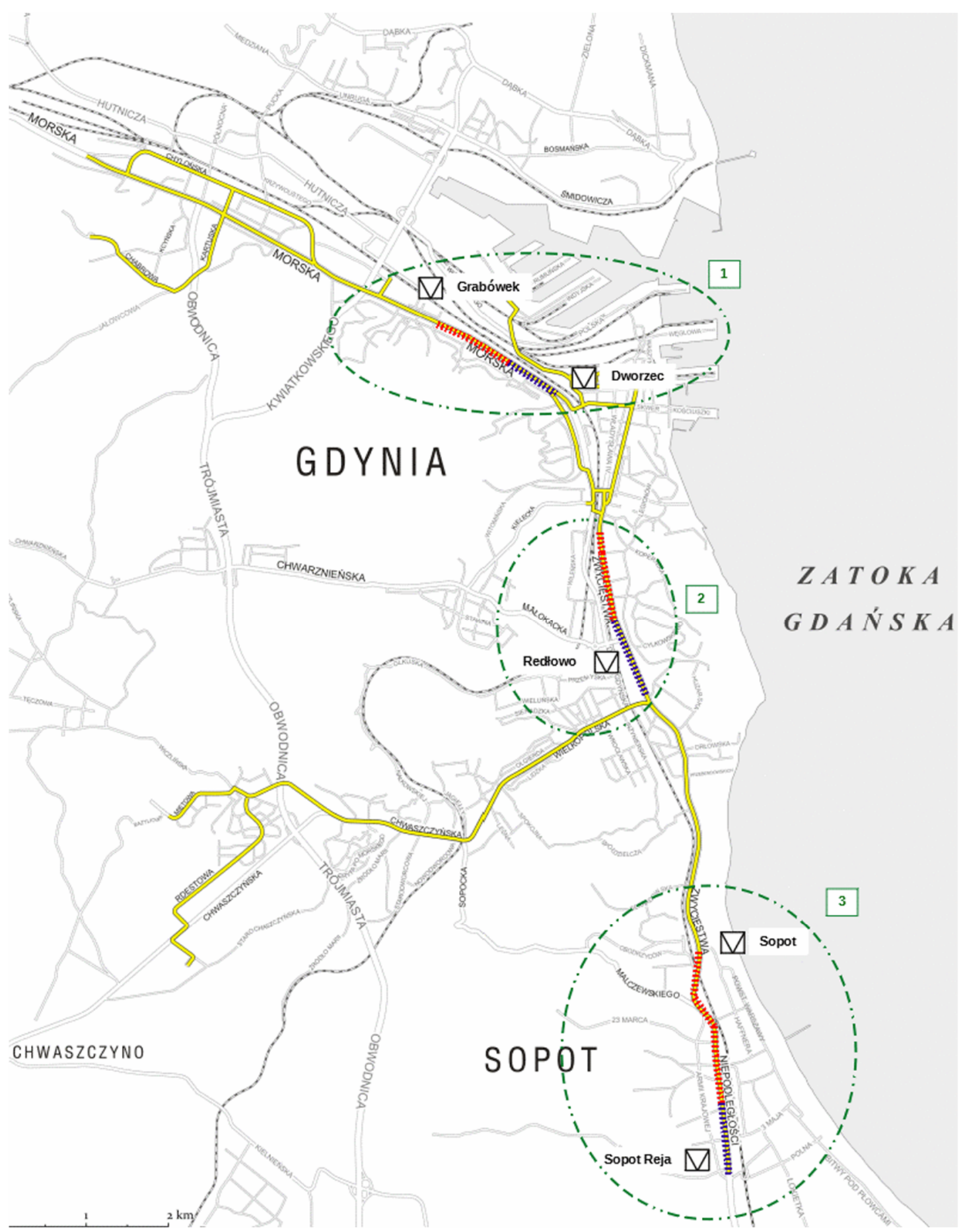

Fig. 6. The scheme of bilateral supply systems, section working in bilateral supply systems are pointed red and blue. 
The coordination of several voltage levels plays as important. In order to ensure the energy recuperation between two vehicles the breaking vehicle should generate voltage higher than supply voltage of acceleration voltage. This voltage difference should be enough to overcome the resistance of catenary. In case of too big voltage difference between vehicles the voltage of breaking vehicle should exceed the threshold level of resistance breaking $(770 \mathrm{~V})$. Moreover, when recovered energy flows through busbars of traction substation (breaking and accelerating vehicle are localized on two different supply section of one traction substation), the generated voltage should exceed the no-load level of traction substation $(720 \mathrm{~V})$. This issue is expressed by voltage dispersion in function of localization.

Fig. 7 presents the voltage values in catenary during acceleration (blue points) and breaking (red points), localization values $0 \mathrm{~km}$ (left side of graph) equals to localization of substation Sopot, $2,5 \mathrm{~km}$ (right side) means substation Sopot Reja. The two main groups of points are visible: one with the voltage value around 770 $\mathrm{V}$, which equals breaking recovery of vehicle and second with the value under $720 \mathrm{~V}$, mean the acceleration of vehicle. The structure of supply system should enable recovered energy flow which is caused by the voltage differences between these group

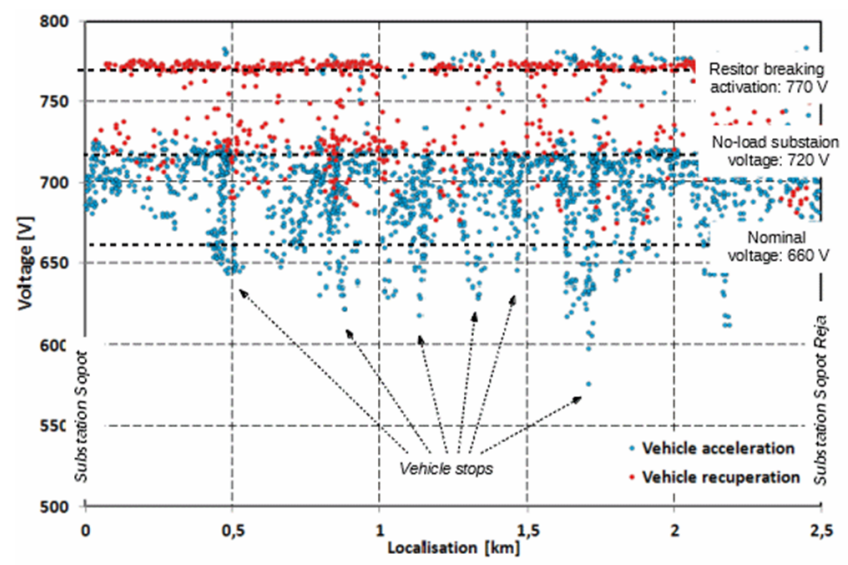

Fig. 7. Spread of the catenary voltage value in area of substations Sopot - Sopot Reja in function of localisation. Red points - vehicle braking (recuperations), blue points - vehicle acceleration. The groups of points, which mean voltage drops during acceleration near stops, are shown.

Figs. 8 and 10 show the time-current characteristics of power supplies before and after the bilateral power supply. Implementation of the bilateral supply resulted in reducing the maximal value of feeder's current up to $40 \%$. Due to asymmetric structure of supply system, the current reduction of feeders working in parallel hasn't the equal value. An important issue relating to the implementation of bilateral power supply in traction supply system is to ensure effective breaking capacity. In the case of long power sections supplied from two substations, there may be a situation where short-circuit current is too low for effective switching of a protection device. However, it is possible to provide adequate protection against short-circuits by means of timecurrents. Fig. 10 shows the detection of short circuit current in the two-sided power supply on the example of the section. In Grabówek-Dworzec section, the minimum short-circuit current is $1100 \mathrm{~A}$.

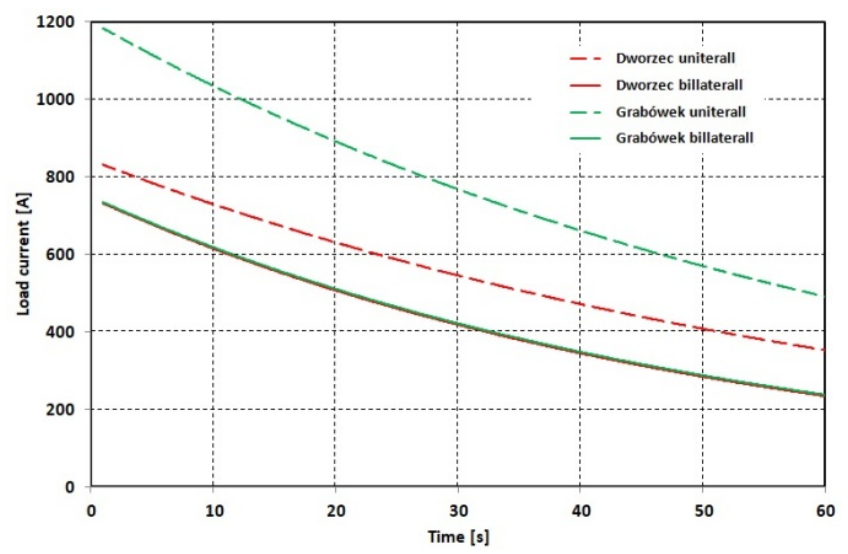

Fig. 8. Time - current characteristic of load feeders from substations Dworzec and Grabówek before and after installation bilateral supply.

Table. 1. Effects of introducing bilateral supply system.

\begin{tabular}{|c|c|c|}
\hline & Unilateral supply & Bilateral supply \\
\hline \multicolumn{3}{|c|}{ Sopot - Sopot I } \\
\hline $\begin{array}{c}\text { Recovery } \\
\text { effectiveness }\end{array}$ & $2,5 \%$ & $10 \%$ \\
\hline $\begin{array}{l}\text { Transmission } \\
\text { Losses }\end{array}$ & $4,6 \%$ & $3,2 \%$ \\
\hline $\begin{array}{l}\text { Voltage drops } \\
<550 \mathrm{~V}\end{array}$ & $0,23 \%$ & $0 \%$ \\
\hline $\begin{array}{c}\text { Voltage drops } \\
<500 \mathrm{~V}\end{array}$ & $0,01 \%$ & $0 \%$ \\
\hline \multicolumn{3}{|c|}{ Dworzec-Grabówek } \\
\hline $\begin{array}{c}\text { Recovery } \\
\text { effectiveness }\end{array}$ & $19 \%$ & $22 \%$ \\
\hline $\begin{array}{c}\text { Transmission } \\
\text { losses }\end{array}$ & $11,2 \%$ & $7,1 \%$ \\
\hline $\begin{array}{l}\text { Voltage drops } \\
<550 \mathrm{~V}\end{array}$ & $0,93 \%$ & $0,01 \%$ \\
\hline $\begin{array}{l}\text { Voltage drops } \\
<500 \mathrm{~V}\end{array}$ & $0,38 \%$ & $0,09 \%$ \\
\hline \multicolumn{3}{|c|}{ Redłowo } \\
\hline $\begin{array}{c}\text { Recovery } \\
\text { effectiveness }\end{array}$ & $12,4 \%$ & $13,3 \%$ \\
\hline $\begin{array}{c}\text { Transmission } \\
\text { losses }\end{array}$ & $6,8 \%$ & $2,9 \%$ \\
\hline $\begin{array}{l}\text { Voltage drops } \\
<550 \mathrm{~V}\end{array}$ & $3,6 \%$ & $0,05 \%$ \\
\hline $\begin{array}{l}\text { Voltage drops } \\
<500 \mathrm{~V}\end{array}$ & $1,1 \%$ & $0,04 \%$ \\
\hline
\end{tabular}

Under normal conditions in spring months, the maximum load current is $765 \mathrm{~A}$. However, due to the potential for increased energy consumption during winter or complicated traffic conditions, a $50 \%$ increase in load should be expected. This corresponds to a maximum current of $1148 \mathrm{~A}$. The current protection may be activated by this load (exclamation mark on Fig. 10). However, based on the 10 seconds average of the 
protection, it is possible to get a reserve between the maximum load current and the minimum short-circuit current (arrow mark on Fig. 10). Consequently, it is possible to operate the short-circuit protection circuit correctly. It should also be noted that the time-current characteristics of the load (Figs. 8, 9) are well below the thermal characteristics of the power cables and traction networks designated for adiabatic heating.

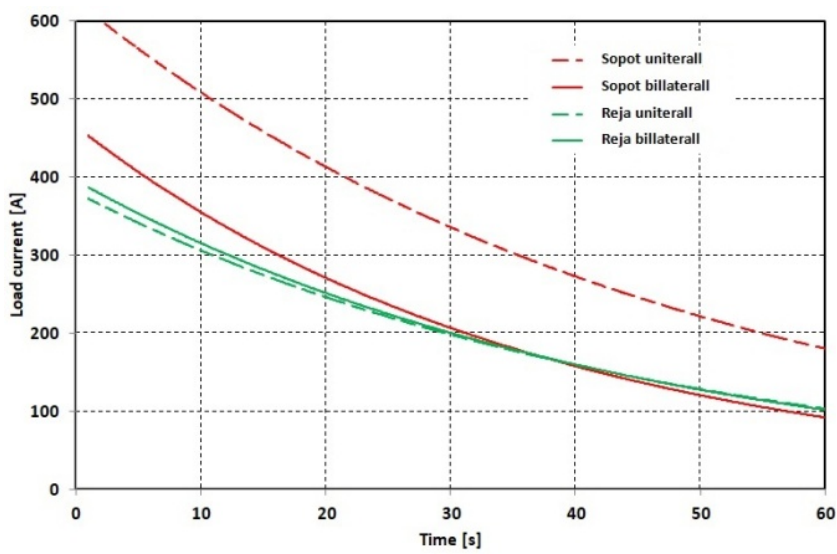

Fig. 9. Time - current characteristic of load feeders from substations Sopot and Reja before and after installation bilateral supply.

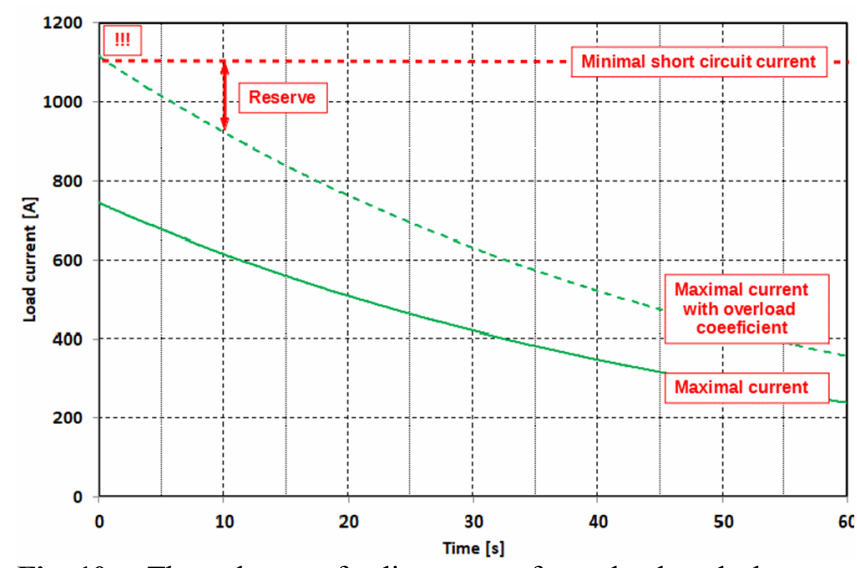

Fig. 10. The scheme of adjustment of overload and shortcircuit protection system in bilateral supply.

\section{Conclusions}

Bilateral supply system allows to reach the energy savings and improvement of supply parameters with small investments. It can be recommended especially for weak supply systems or decentralized systems with many small substations, which makes the flow of recuperated energy difficult. Moreover, the bilateral supply allows to reduce voltage drops in supply network.

To increase the use of energy recovery, at first it is necessary to consider the possibility of reconfiguring the supply system, which will facilitate the flow of braking energy. In many situations, very good results can be achieved at a low cost. Small substation power supply areas galvanically isolated from the rest of the network should be avoided. Supply areas of such substations should be connected to create the largest area of recuperation energy flow. Therefore, it is recommended to introduce bilateral supply of the overhead line to allows for an increase in the utilization rate of recuperation and reduced transmission losses.

This paper has been elaborated in the framework of the project ELIPTIC "Electrification of public transport in cities" co-financed by the European Union's Horizon 2020 research and innovation programme under the grant agreement No 636012

\section{References}

1. Hebel, K., Wołek, M., Perception of modes of public transport compared to travel behaviour of urban inhabitants in light of marketing research, Scientific Journal of Silesian University of Technology. Series Transport, 92, 65-75 (2016),

2. Bartłomiejczyk, M., Połom, M., The impact of the overhead line's power supply system spatial differentiation on the energy consumption of trolleybus transport: planning and economic aspects, Transport, 32, 1-12 (2017)

3. Kacor, P., Marek, M., Palecek, J., Analysis Of Magnetic Field Distribution Inside Tram-Car, Proceedings Of The IV International Scientific Symposium On Electric Power Engineering Elektroenergetika 2007, 128-129 (2007),

4. Jarzebowicz, L., Karwowski, K., Kulesza, W. J., Sensorless algorithm for sustaining controllability of IPMSM drive in electric vehicle after resolver fault, Control Engineering Practice, 58, 117-126 (2017)

5. Jarzebowicz, L., Judek, S., 3D Machine Vision System for Inspection of Contact Strips in Railway Vehicle Current Collectors, International Conference on Applied Electronics (AE), Pilsen, Czech Republic, 139-144 (2014).

6. Hamacek, S., Bartlomiejczyk, M., Hrbáč, R., Misak, S., Styskala, V., Energy recovery effectiveness in trolleybus transport, Electric Power Systems Research, 112, 1-11 (2014)

7. Bartłomiejczyk, M., Połom, M., Multiaspect measurement analysis of breaking energy recovery, Energy Conversion and Management, 127, 35-42 (2016)

8. Hrbáč, R., Kolář, V., Mlčák, T., 2015. Distributed measurement system with GPS synchronisation and its use in electric traction, Elektronika ir elektrotechnika, 21, 8-13 (2015)

9. Hrbáč, R., Mlčák, T., Kolár̆, V., Improving Power Quality with the Use of a New Method of Serial Active Power Filter (SAPF) Control, Elektronika ir Elektrotechnika, 23, 15-20

(2017) 